\title{
Initial Implementation of Productive Migrant Village (PMV) Programs in Banyumas Central Java Indonesia
}

\author{
Muslihudin ${ }^{1, *}$, T R Wulan ${ }^{1}$, T Sugiarto ${ }^{1}$, S Wardhianna ${ }^{1}$, S Wijayanti ${ }^{2}$. \\ 1. Sociology Department, Faculty of Social and Political Sciences, Jenderal Soedirman University, Purwokerto, \\ Indonesia. \\ 2. International Relation Department, Faculty of Social and Political Sciences, Jenderal Soedirman University, \\ Purwokerto, Indonesia.
}

*Corresponding author: muslihudin1963@yahoo.com

\begin{abstract}
Since 2017 Banyumas Regency has received a program from the Ministry of Manpower and Cooperatives to become a pilot program for productive migrant village programs. The village that was used as a pilot was Cihonje village, Gumelar district and Losari village, Rawalo district. The program has been determined that is to realize the four productive migrant village pillars which include; 1). Providing migration information and services, 2). Developing productive business, 3). Facilitate the establishment of community care and growth (community parenting), 4). Facilitating the establishment and development of cooperatives/financial institutions. The four programs have been strived to run quickly by the two pilot villages, with various tools being formed from personnel, software, and hardware. The implementation of productive migrant village program in Banyumas Regency is still not implemented on the four pillars. Productive business programs are the most desirable programs by both villages in implementing productive migrant village. On the contrary, cooperative formation programs are programs that have not been carried out. The information-giving program also includes programs that are not going well because there is resistance to the interests of private employment agencies that have been sending Indonesia migrant worker (IMW) so far. Community parenting programs are also classified as programs that are still not optimal because they do not involve the community as caregivers of IMW's children. The positive expectations from the Cihonje village community and Losari village are also the initial capital for the success of the productive migrant village program. However, the success of the productive migrant village program remains with the government because this program is a top-down planning program. For that sustainability must be done if the program does not want to be just a memorable program as other projects over the years.
\end{abstract}

\section{Introduction}

Indonesia as a country with a large population has employment problems is a common thing. The high workforce demands many jobs. When domestic conditions are unable to meet these demands, the alternative is to seek employment abroad or become an Indonesian migrant worker (IMW). It has been a long walk, that domestic employment coupled with wage disparities that much different from abroad. Based on data from the National Agency for the Placement and Protection of Indonesian Migrant Workers (BNP2TKI), in 2015 there were 6, 5 million Indonesian migrant workers (IMW) working in 142 countries 
around the world. The high number of IMWs working abroad was not offset by adequate protection by the state for IMWs. In 2013, based on data from the BNP2TKI Crisis Centre, there were at least 13 thousand cases affecting IMW in various countries, 300 of which were threatened with death sentences (9).

The number of cases that have been fall IMW abroad is due to the lack of knowledge, experience, and information possessed by workers (Latifah et al, 2016). IMW usually departed is still not fully prepared about various matters related to regulations, culture, values, and customs in the destination country. In other words, people who want to go to work abroad have not received accurate information to work abroad in accordance with the legislation (5).

In connection with the income earned from working abroad, IMW generally has the aim of being able to improve the standard of living later when it is finished work. Even many of them are aiming for money for business capital. But in reality, the purpose of the destination remains because a lot of money from his work is spent only on the consumption needs of the family left behind. In other words, many IMWs have not been able to utilize the work they have obtained for business ventures that are productive, but more consumptive.

Another problem that is common in the IMW family is related to the children they left behind. We know that most IMW are women. Their children are abandoned by their mothers for years, so IMW's children automatically lose guidance and care from their mother or father. In other words, PM I's children do not get guidance and education the good one because his parents aren't complete. On this basis, the government feels the need to create a coordinative program integrated to answer all problems in above that is with the PMV program.

The intent and purpose of the productive migrant village itself specifically (5). juggling a number of non-procedural migrant workers; 2) realize a productive society and a family of prosperous Indonesian migrant workers in the village of origin; 3) provide labour information and migrant services at the village level; 4) empower family of TKI and ex TKI and their families; and 5) encourage the active role of village government in the villages originating from TKI and all stakeholders.

PMV is in line with Law No. 6 of 2014 concerning Villages which provides space for villages to increase the broadest possible village initiatives to protect and prosper the villagers.Program Target The number of villages is 400 villages by 2019 with details: In 2017 there were 120 villages, covering 100 villages in 50 regencies/cities of Indonesian migrant workers, and 20 villages in 10 regencies/cities of NTT Province. In 2018 there were 130 villages. In 2019 there were 150 villages.

\section{Materials and Methods}

This research was conducted since February 2017 in Banyumas Regency, which is one of the districts that received Productive Migrant Village Programs from the Ministry of Manpower and Cooperatives. The research site is Cihonje Village, Gumelar District and Losari Village, Rawalo District. The location selection was based on the consideration that the PMV Program had been implemented in the two villages. In accordance with the provisions stipulated by the Ministry of Manpower and Cooperatives, these two villages are the representation of villages in Banyumas Regency. the two villages are a PMV program pilot project in Banyumas Regency. Thus the results of this study can be used as a reference for adoption in other villages that are implementing the PMV program.

Data collection methods are in-depth interviews, observation and focus group discussions (FGD). Data analysis was carried out both in the field and after data was collected. Data that has been collected, then processed to be systematic. Processes start from writing interviews, observing, editing, classifying, reducing, presenting data, and summarizing data (Miles, 2014). 


\section{Results and Discussion}

\subsection{PMV as a National Program}

PMV is the central government program, especially the ministry of labour and cooperatives. Thus the productive migrant village program is a top-down planning program. As the top-down program (1) will be conducted effectively as planners, implementers and assessors also the government itself. Thus it does not need too much community participation except only as a program object. In addition, the community is also not required to contribute to its programs because the costs are borne and budgeted by government funds. Goals and targets mainly quantitatively would be achieved with to fast as planned. Muslihudin et al (6) also said that the top-down implementation is marked by a very big role of central government as a "commander", so that it needs technical guideline in the village society.

On the other hand, a top-down program has consequences that the community is not active so that the community in the region does not have creativity, lack initiative and tend to come from the road even ignorant. According to Marini (4), there are three approaches to development planning, namely a technocratic approach that is top down, a combination of top-down and bottom-up approaches, and a community-based/participatory approach. A technocratic or top-down approach is more dominant in various ministries including in the forestry ministry.

In the top-down planning system, on the side the community cannot monitor, also tends to be reluctant to criticize, does not know the process of running a program, the program is difficult to be fully achieved because the community does not know from the start, the community also lacks participation because their votes are not taken into account in the process of running a process. Rosyadi (8) said that the fundamental weakness of development in Indonesia was due to bad governance. The dominance of the role of the bureaucracy feels so strong in determining the process of procuring a decision until the implementation of various development programs. The role of the community is more at the level of implementation. As a result, the level of community dependence on the bureaucracy is increasing.

As a national program, the program content is the same for all the PMV pilot program villages. PMV program consists of 4 (four) main integrated activities implementation, support and expected on going.

\subsubsection{Providing Information and Migrant Services.}

Through the Employment Information and Migration Services Centre, villagers who want to work at home and abroad get services on labour market information, work guidance/counselling (i.e. information through training), information on how to become procedural migrant workers, and document making services for prospective labour migrants as requirements for the creation of a passport (such as KTP, KK, certificate, and other documents) carried out at the village hall through an active role from the village government. The centre also works to help resolve the problems of migrant workers by providing a reference to the competent authorities (i.e. police, labour offices, BP3TKI, or NGOs).

\subsubsection{Develop Productive effort.}

Helping Indonesian labour migrants and their families to have the skills and willingness to grow productive businesses through training, mentoring, and assistance in productive business facilities to marketing. 


\subsubsection{Facilitating Community as Parenting (Community Parenting).}

Assist the community in the formation of a community whose task is to provide guidance to the families of Indonesian labour migrants in terms of educating, nurturing and guiding children properly and correctly. Through this activity, the TKI children are cared for together by the community in a teaching and learning centre called "learning house" productive migrant village. Parents and couples who live at home are given training on how to raise, care for, educate, and guide children properly and correctly so that they can continue to go to school and develop their creativity.

\subsubsection{The government established and Developing Cooperative Institute/Finance.}

Establish and develop cooperatives/financial institutions that aim to strengthen people's productive efforts for the long term and sustainable.

\subsection{Implementation in Banyumas Regency}

\subsubsection{Cihonje village Gumelar district}

Base on prominent PMV program implementation in Cihonje village, Gumelar District are:

Raising Rabbit. Rabbit cultivation as a form of developing productive businesses is carried out by several IMW families. The activity is to utilize the resources in the hilly area so that raising livestock is a conducive business. The aspect of distribution or sale of livestock products is very easy because the demand for rabbit meat is very high from the cities of Purwokerto and Baturraden. Even the high demand for rabbit meat cannot be fulfilled by rabbit farmers in Cihonje village. The problem that is often faced by rabbit breeders is related to the pests or health of rabbits which are sometimes in pain even to death. The knowledge of raising rabbits is required to know in more detail so that it can overcome if there are problems with rabbits.

Snack Craft. Preparation of snacks made from cassava is also a mainstay of the productive effort of the IMW. The results of the training were called "Cantirku". Actually the food craft is quite appropriate for the PMVs of Cihonje village because cassava is indeed produced in the village. The constraint is the raw material to make my certificate not from the results of the process itself, but the results of the purchase of a private company, IMW only fry and then packed. Even though there was already assistance for the equipment to process from cassava to semi-finished material which was a help from the government. The equipment is quite a lot, until now only stored in the PMV study room. Another obstacle is the marketing of handicrafts, some of which are former IMW mothers. Because marketing while still in the village itself, has not been able to penetrate into other areas. In this case, people who have an entrepreneurial spirit are needed.

Community Parenting, the care of IMW's children is carried out in the form of providing courses in subjects that have been difficult for elementary and junior high school students, such as courses in English, mathematics and science. It was also only limited to being close to PMV learning houses. Care in the form of advocacy for problematic IMW children in schools has also been assisted by a PMV program assistant. However, parenting by the community itself and not by assistants has not emerged as expected by the PMV program. Even people still have the view that IMW children are indeed worthy of trouble. 


\subsubsection{Losari village Rawalo district}

Some prominent PMV program implementation in Losari Village, Rawalo District are:

- $\quad$ Producing Chips Tempe.

The craft done by the former female IMWs is tempe chips with the brand "Citra Sari". Tempe chips are not really new in the Banyumas area because tempe chips have become a home industry. Marketing the craft is still very limited and there is no potential to be great because the packaging is still modest.

- Cultivation of Dragon and Papaya Fruit.

Planting dragon fruit marsh that is intended as marsh grow productive enterprises Losari village seems not obtain significant result. Even the planting of fruit yet to obtain results, the land transfer has occurred. It seems that the planting of dragon fruit is rather forced so it has not shown any meaningful results.

- Information Services.

The provision of information about the process to become an active IMW was carried out by the PMV facilitator of the village of Losari. Although there are obstacles in conveying this information because recruitment agencies / agents of Indonesian Private Employment Agencies (IPEA) who were once known as IESP (Indonesian Employment Service Providers) do not want the program. The information service program makes IMW candidates become aware of clear procedures so they tend not to want to go through private channel institutions.

- Community Parenting.

In terms of the care of IMW children, the Losari village PMV is also the same as the Cihonje village which is the provision of English and mathematics courses at the productive migrant village (PMV) learning house. This means that the care of children by the community has not yet been realized as in other villages.

The implementation of several programs in two PMV villages is still very poor to say successful. This is understandable because it has only been running for one and a half years. However, if it is read from the implementation of the two villages, the productive business program is the program most in demand by former IMWs. The program that seems not to be in demand or is running is the formation of cooperatives. Community parenting programs also seem to be far from expectations. However, this kind of program needs to be considered about program optimization and sustainability. Because often these top down programs need serious and sustainable efforts so that the program does not end in vain.

Leksono et al (3) who reviewed the Mandiri Energy Village Program from the Ministry of Energy and Mineral Resources also produced a recommendation that the success of the program must be completed by the mentoring program. Supported by subsidies from the government to actually succeed in accordance with was expected. Because it is not complete, the assistance and facilities will only stall as in the energy independent village program.

\section{Conclusion}

Productive migrant village program is a program of nation all applicable in all Indo $\mathrm{n}$ e waste. PMV is applied to villages that contribute the largest Indonesian migrant workers. Targets are planned until 2019 are 400 villages that will receive PMV program. Because this program is a top down planning program, it is uniform in all villages that get the program. The effectiveness can be achieved in accordance with the benchmarks of the government. Community participation in the PMV program is also estimated to be less optimal.

Implementation in Banyumas regency, especially in Cihonje village, Gumelar district and Losari village, Rawalo district observations in the same outline, is that productive business programs are the most popular programs to run. On the contrary, making cooperatives is a program that has not yet appeared. The information-giving program for prospective IMWs is a program that deals with private employment agencies that have been mastering the departure of workers abroad. Community parenting programs are 
also programs that seem difficult to materialize well.

\section{Acknowledgment}

Our thanks to the Institute of Research and Public Services (IRPS) Jenderal Soedirman University, the funders of this research. We would also like to thank the office of the Ministry of Manpower in Banyumas Regency for cooperating in strengthening the PMV program. Thank you also to the Village Head of Cihonje and Losari who gave permission for the research team. Also for companion PMV Cihonje Village (Yuli and Indra) and companion PMV Desa Losari (Renate and Arif).

\section{References}

[1] Kusumanegara S., Muslihudin, Ahdiati T. 2015. Carrying Forest Village Community Institution of Program Energy Independent Village, LPPM, Jenderal Soedirman University, Purwokerto.

[2] Latifah SW., Waluya AJ., Retna ER. 2016. Empowerment of Ex-Tki Through Local PotentialBased Business Development Journal of Business, Management \& Banking Vol. 2 No. 1.2016: 6780

[3] Leksono B., Muslihudin, Kusumanegara S. 2014. Development of Nyamplung Social and Economic Studies in Cilacap and Purworejo, Swara Politika Journal, Faculty of General Soedirman University, Purwokerto, edition vol. 13 pp. 69-79.

[4] Marini A., 2013. Study of the Effectiveness of Forestry Development Planning in the Perspective of Strategic Planning, Scientific Journal of Public Administration, Volume 14, Number 1, June 2013, p.398-411

[5] Ministry of Manpower, 2017, PMV: Productive Rural Migrants and Protect Indonesian Migrant Workers Building from Villages, Head of Research and Development Ministry of Manpower Jakarta.Miles BM., Huberman AD,, Saldana J. 2014. Qualitative Data Analysis: A Sourcebook method. Third Edition Copyright SAGE Publications. Inc. Washington.

[6] Muslihudin M., Kusumanegara S., Ahdiati T. 2015. The Program Implementation of Energy Self Sufficient Village based on Calophyllum Inophyllum in Purworejo, Central Java, Indonesia. Proceeding of International Conference on Green Technology ISSN:2355-3456

[7] Republic of Indonesia, 2014. Law Number 6 of 2014. concerning Villages.

[8] Rosyadi, S. 2010. The New Paradigm of Development Management, First Edition, Gava Media Publisher, Yogyakarta.

[9] Wulan T.R., Muslihudin M., Sugiarto T., Wardhianna S., Wijayanti S. 2018. Gender Relations in Implementation of "PMV" (Productive Migrant Village). International Conference on Gender and Development, Makassar, Indonesia. 